\title{
Testing of Agricultural Tractor Engine using Animal-fats Biodiesel as Fuel
}

\author{
Youngjung Kim*, Siyoung Lee, Jonggoo Kim, Donghyeon Kang, Honggi Choi \\ Energy \& Environmental Division, Department of Agricultural Engineering, \\ National Academy of Agricultural Science, Rural Development Administration, Suwon, Republic of Korea
}

Received: July 19 ${ }^{\text {th }}, 2013$; Revised: August $2^{\text {th }}, 2013$; Accepted: August $7^{\text {th }}, 2013$

\section{Abstract}

Purpose: Performances of a tractor diesel engine fueled by three different animal fats biodiesels were evaluated comparing with light oil tractor in terms of power, fuel consumption rate, exhaust gases, particulate matter amount and field work capacity. Methods: Animal fats based on pig biodiesel were manufactured manually and tested for its engine performance in the tractor diesel engine and fuel adoptability in the field works. Four different fuels, three different content of biodiesel (BD20, BD50, BD100) and light oil, were prepared and tested in the four strokes diesel engine. Power output, fuel consumption rate and exhaust gases of the four fuels in the diesel engine were compared and discussed. Results: Power output of light oil engine was the greatest showing 5.3\% difference between light oil and BD100, but $0.37 \%$ better power than $\mathrm{BD} 20$ engine power. Less exhaust gases of $\mathrm{CO}_{2}, \mathrm{CO}, \mathrm{NO}_{\mathrm{x}}$ and $\mathrm{THC}$ were produced from animal fats biodiesel than light oil, which confirmed that biodiesel is environmental friendly fuel. For fuel adoptability in the tractor, biodiesel engine tractor showed its fuel competitiveness comparing with light oil for tractor works in the faddy field. Conclusions: With four different fuel types of animal-fats biodiesel, performances of a four cylinder diesel engine for tractor were evaluated in terms of power, exhaust gases, particulate matters (PM) and field work capacity. No significant differences observed in the engine performances including power output and exhaust gases emission rate. No significant power difference observed between the various fuels including light oil on the engine running, however, amounts of noxious exhaust gases including $\mathrm{CO}_{2}$ and $\mathrm{NO}_{\mathrm{X}}$ decreased as biodiesel content increased in the fuels. Field performances of animal-fats biodiesel tractor were investigated by conducting plowing and rotary operation in the field. Tilling and rotary performance of light oil tractor and BD20 tractor in the field were compared, in which about 10\% travelling speed difference on both operations were monitored that showed light oil tractor was superior to BD20 tractor by $10 \%$. Animal-fats can be an alternative fuel source replacing light oil for agricultural machinery and an environmental friendly fuel to nature.

Keywords: Animal-fats, Biodiesel, Diesel engine, Exhaust gases, Particulate matters, Performance, Tractor

\section{Introduction}

Biodiesel can be used in pure form, or blended in any amount with diesel fuel for use in compression ignition engines. It is produced through the reaction of a vegetable oil with methyl alcohol or ethyl alcohol in the presence of a catalyst. Animal fats can be one resource for biodiesel with almost the same procedure of plant oil biodiesel production method. Commonly,

\footnotetext{
*Comesponding author: Youngjung Kim

Tel: +82-31-290-1828; Fax: +82-31-290-1840

E-mail: kim0yoj@korea.kr
}

used catalysts are potassium hydroxide $(\mathrm{KOH})$ or sodium hydroxide $(\mathrm{NaOH})$. The chemical process is called transesterification which produces biodiesel and glycerin. Since biodiesel has eleven percents more oxygen by weight basis compared to light oil, it has superior combustion qualities than diesel fuel in nature and discharges less $\mathrm{CO}, \mathrm{SO}_{\mathrm{x}}$ and $\mathrm{NO}_{\mathrm{x}}$ that contribute to making better atmosphere environment. Biodiesel is also widely used for heating fuel in European countries. Numerous studies of biodiesel fuel affecting on diesel engines has been conducted in several European countries and North American regions. Those biodiesel engines 
tested with biodiesel fuels are mainly commercials passenger cars or big transportation trucks and construction vehicles. But, studies of biodiesel adoptability test for agricultural tractor engines are hardly found and several domestic agricultural tractor manufacturers having bigger abroad market shares are very interested in the long term effects of biodiesel fueled engine. According to Kim et al. (2010), biodiesel fueled tractor with BD20 and BD100 could accomplish the same quality works of tillage and plowing by a diesel fueled tractor, though small fuel consumed amount differences found where as biodiesel content increased fuel consumption increased. The largest difference was 10\% between BD100 and diesel fuel of plowing operation. And, $\mathrm{CO}_{2}$ discharged amount was less in biodiesel tractor than in diesel tractor, but $\mathrm{NO}_{\mathrm{x}}$ discharged amount was on the contrary. Several biodiesel fueled engine durability tests were conducted by Prankl et al. (2006), where single cylinder engine $(673 \mathrm{cc}$ ) durability test for biodiesel hrs was carried out by Choi et al. (2006; 2007) for 150 hours. Generally, engine specialists accept that BD5 is ok for diesel engines without any engine modifications, and BD20 is a short-term goal for biodiesel dissemination in transportation vehicles. In fact, BD20 is widely and slowly gaining its footholds in European countries and North American regions. According to a study (Wilson, 2003), 20\% biodiesel combusting internal diesel engines discharge polluted matters $20 \%$ less, carbon monoxide $12 \%$ less, fine dust $12 \%$ less, $\mathrm{NO}_{\mathrm{x}} 2 \%$ more, $\mathrm{SO}_{\mathrm{x}} 20 \%$ less and aromatic chemicals $13 \%$ less than those of light oil. The reason for $\mathrm{NO}_{\mathrm{x}}$ incremental is that, again, more oxygen amount in biodiesel than light oil. For biodiesel usage practice for agricultural tractor (Kim et al., 2010), more biodiesel fuel, about $30 \%$ to $40 \%$, for tractor operation such as tilling and plowing was needed than light oil, and it was reported that troubles such as no ignition or abrupt stopping were not monitored during the works of plowing, rotary tilling and travelling on the road. Pour points of the biodiesels were higher than light oil, and biodiesel content ratio increased pour point increased. About $15 \mathrm{cSt}$ was the pour point of biodiesels and light oil, which occurred at 3 to $4^{\circ} \mathrm{C}$ in the biodiesels and at $-25^{\circ} \mathrm{C}$ in the light oil (Kim et al., 2008). Biodiesel is also coming from animal-fats. In Korea, about 400 thousand tons of animal-fats are produced annually that can be transformed to biodiesel of $315,000 \mathrm{~kL}$, equivalent to $25 \%$ of total tax-free fuel consumption amount $(1,264$ thousand $\mathrm{kL})$ for protected crops production industry. Cow and swine fats are the main resources for animal-fats biodiesel production. Animal-fats biodiesel produced in the USA was about 450 million litres in 2008 that was taking up 20\% of the total biodiesel production amount in 2008 (Goodfellow, 2010). The objective of this study was to evaluate the performance of tractor disel engine fuelled by animal-fats biodiesel comparing with light oil tractor diesel engine.

\section{Materials and Methods}

\section{Tested engine}

A engine used for this investigation is a vertical type water cooled 4 cycle diesel, displacement of 1,999 $\mathrm{cm}^{3}$, power output of $34 \mathrm{~kW}$ at 2,600 rpm, manufactured by a domestic tractor company (Table 1).

\section{Prototype fuel}

The biodiesel used for this experiment was manufactured manually with pig fats through completing five processing steps of size reduction, extracting oil by micro oven heating, methoxide reaction, separating biodiesel from glycerin and washing and drying (Kim et al., 2012). The biodiesel made of pig fats was inspected for its quality by K-Petro and satisfied most of requirements of BD100 specification (Kim et al., 2012). Table 2 shows major fuel quality index of the fuels used in this study. Of which, the major difference between BD100 and light oil is Fatty Acid Methyl Ester (FAME)

\section{Table 1. Specifications of the engine}

\begin{tabular}{|c|c|}
\hline Make/Model & DAEDONG INS./ 4A220LWS \\
\hline Type & $\begin{array}{c}4 \text { stroke diesel engine, direct } \\
\text { injection }\end{array}$ \\
\hline \multicolumn{2}{|c|}{ Dimensions } \\
\hline length & $430 \mathrm{~mm}$ \\
\hline width & $450 \mathrm{~mm}$ \\
\hline height & $490 \mathrm{~mm}$ \\
\hline weight & $48 \mathrm{~kg}$ \\
\hline \multicolumn{2}{|c|}{ Cylinders } \\
\hline number/ disposition & $4 /$ vertical in-line \\
\hline bore/stroke & $83 \mathrm{~mm} / 92.4 \mathrm{~mm}$ \\
\hline capacity & $1,999 \mathrm{~cm}^{3}$ \\
\hline compression ratio & $21.7: 1$ \\
\hline
\end{tabular}




\begin{tabular}{|c|c|c|}
\hline Property & BD100 & Light oil \\
\hline FAME $(\%, W)$ & 95.5 & 1.54 \\
\hline Flash point $\left({ }^{\circ} \mathrm{C}\right)$ & 180.5 & 48 \\
\hline Viscosity@40 $\left(\mathrm{mm}^{2} / \mathrm{s}\right)$ & 4.945 & 2.245 \\
\hline Density@15C (kg/m³) & 883.7 & 824.1 \\
\hline Calorific value $(\mathrm{J} / \mathrm{g})$ & 40,000 & 45,567 \\
\hline
\end{tabular}

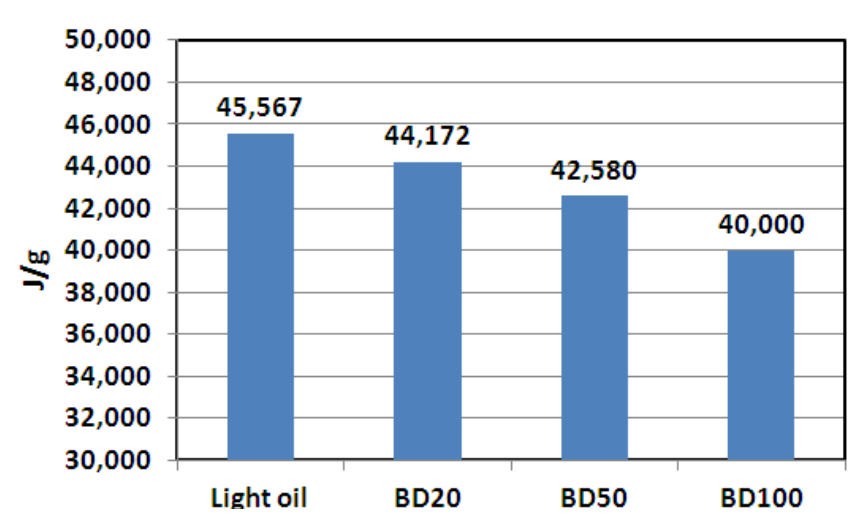

Figure 1. Calorific vaues of the different animal-fats biodiesel (Kim et al., 2012).

amount in the fuel that BD's FAME was $95.5 \%$ but $1.54 \%$ for light oil. Kinematic viscosity was 4.945 $\mathrm{mm}^{2} / \mathrm{s}$ at $40^{\circ} \mathrm{C}$ for BD100 and 2.245 for light oil. Calorific value for BD100 and light oil was 40,000J/g and $45,722 \mathrm{~J} / \mathrm{g}$ (Figure 1). It revealed that calorific value of $\mathrm{BD} 100$ was lower than light oil by $12.5 \%$. However, BD is usually blended with light oil making BD5 or BD20 form, thus calorific value difference is less than $5 \%$ in the actual usages. With the $100 \%$ pure biodiesel (BD100), four different fuels were prepared for this test; BD20, BD50, BD100 and light oil. BD20 meant biodiesel $20 \%$ mixed with light oil $80 \%$ in weight basis and BD100\% was pure biodiesel BD100\% mixed with light oil $0 \%$ (Kim et al., 2012).

\section{Measurement system}

The diesel engine was situated on the engine bed and connected to the dynamometer (AG400, AC110 $\mathrm{kW} / 5,000 \mathrm{~m}^{-1}$, United Kingdom, Froude Ltd.) as shown in Figure 2. With the four fuels, engine power, fuel consumption rate, composition of discharged gas, PM (particulate matters) amount were measured. For discharge gas analysis, Greenline mk2 (Eurotron, Italy) was employed. For PM measurement, PM system (MDLT-

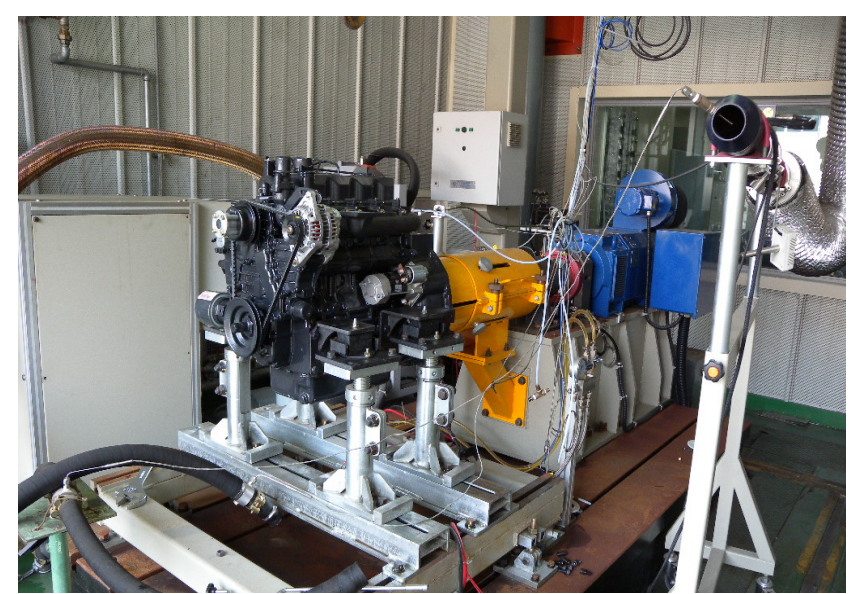

(A) The diesel engine loaded in the test bed

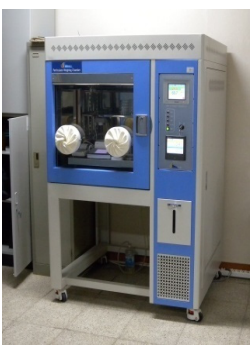

(B) PM weighing chamber

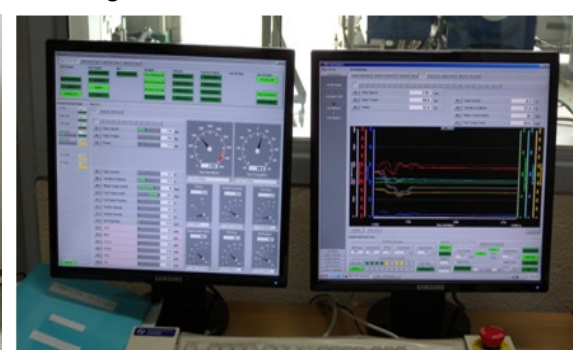

(C) Displaying engine performance
Figure 2. Measurement systems.

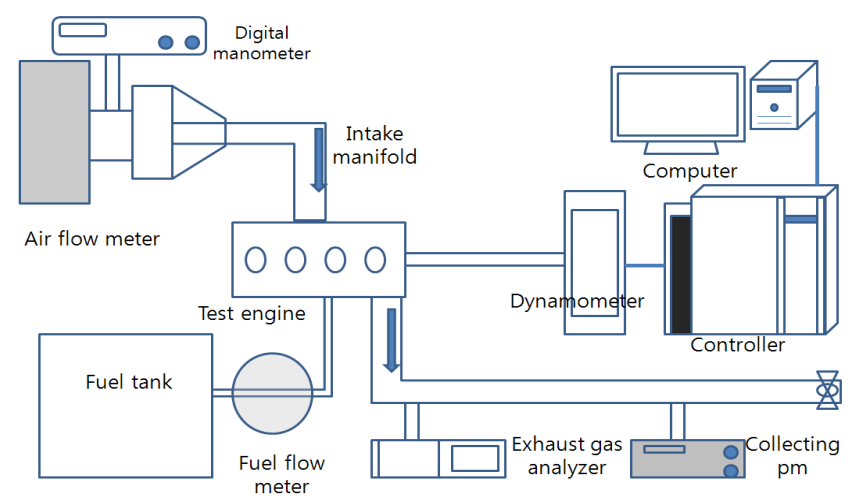

Figure 3. Schematic diagram of experimental apparatus.

1303TMA, Horiba, Japan) and Particulate Weighing Chamber (Daesan Eng., Korea) were used.

In Figure $2(A, B, C)$ shows the diesel engine on the engine test bed, the PM weighing chamber and data collection displaying system. Figure 3 shows the whole experiment apparatus for this measurement system.

\section{Engine test mode}

Various engine test modes are defined by International 
Standard Organization (ISO) (ISO, 2007). In order to measure engine performance with four different fuels we chose $\mathrm{C}$ type test cycle, "Off-road vehicles and industrial equipment", in this experiment. Conventional engine performance is measured at rated speed with full load condition for a period of 1,500 hours mostly, but the test cycle we have developed in Table 3 imitating various engine running patterns (ISO, 2007; Kim et al., 2011). The test cycle composed of three different engine speeds and three different loads mimicking actual engine running conditions of farm operations such as plowing and rotary tilling, so that it can reduce a great deal of test running time of engine (ISO, 2007).

\section{Results and Discussion}

\section{Engine power}

By the test cycle we carried out all the engine tests and collected all the data of the diesel engine performance. For comparison of the four different fuels affecting engine performance, we chose one mode, $2600 \mathrm{rpm}$ with 120 $\mathrm{Nm}$ and running time of 72 minutes. In the Figure 4 , at 2,600 engine rpm and load of $120 \mathrm{Nm}$, engine power of light oil, BD20, BD50 and BD100 was 34.80,

Table 3. The diesel engine test cycle adopted in this experiment

\begin{tabular}{|c|c|c|c|c|c|c|c|c|}
\hline Mode & 1 & 2 & 3 & 4 & 5 & 6 & 7 & 8 \\
\hline Engine speed (rpm) & & 2,6 & 00 & & & 1,700 & & 900 \\
\hline Torque (Nm) & 120 & 90 & 12 & 60 & 140 & 105 & 70 & 20 \\
\hline Duration (min) & 72 & 72 & 48 & 72 & 48 & 48 & 48 & 72 \\
\hline
\end{tabular}

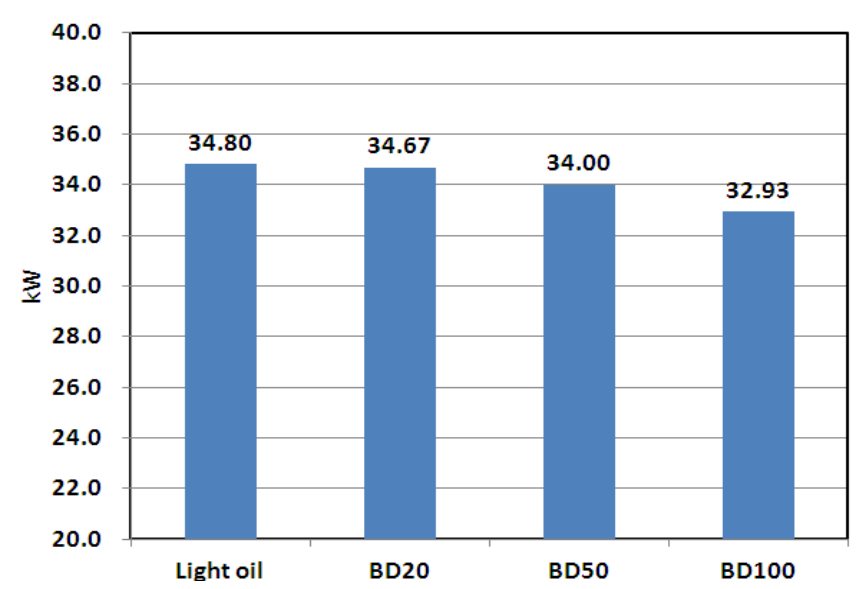

Figure 4. Engine powers of four different fuels.
34.67, 34.00 and $32.93 \mathrm{~kW}$, respectively, showing 5.3\% power difference between light oil and BD100 and less between light oil and other BDs. As expected the greatest power occurred in light oil fueling engine and the smallest power was produced by BD100 engine. Power difference between light oil and BD20 was $0.37 \%$.

\section{Fuel consumption rate}

Figure 5 shows fuel consumption rates of the engine of the four different fuels. It showed that $8.04 \mathrm{~kg} / \mathrm{h}$ light oil was spent at 2,600 rpm with $120 \mathrm{Nm}$ in the dynamometer, while $8.94 \mathrm{~kg} / \mathrm{h}$ of $\mathrm{BD}$ at the same operation condition showing $11 \%$ more fuel needed but $5.3 \%$ less power output by BD100 engine. And, $4 \%$ fuel consumption rate difference was observed between BD20 and light oil engine. During the engine test running period, sudden busts engine stop due to fuels was not monitored.

\section{Exhaust gases}

Major exhaust gases of the diesel engine by four different fuels are shown in the Figure 6, where obvious gas quantity variation existed among the fuels. As BD content increased gas quantity of $\mathrm{CO}_{2}, \mathrm{CO}, \mathrm{NO}_{\mathrm{x}}$ and $\mathrm{THC}$ decreased, which was reported in the previous studies (Kim et al., 2008; 2012). These results confirmed that BD fuel is more nature friendly fuel than fossil fuel. $2.5 \%$ less $\mathrm{CO}_{2}$ produced from $\mathrm{BD} 20$ than light oil at engine running condition of $2600 \mathrm{rpm}$ with $120 \mathrm{Nm}$. $\mathrm{NO}_{\mathrm{X}}$ emission amount of light oil and BD100 engine was 503.37 and 419.15 ppm showing $16.7 \%$ less $\mathrm{NO}_{\mathrm{X}}$ produced from BD100 diesel engine comparing to light oil fueling engine. CO emission amount was 92.91 ppm, 90.00 ppm, 88.00

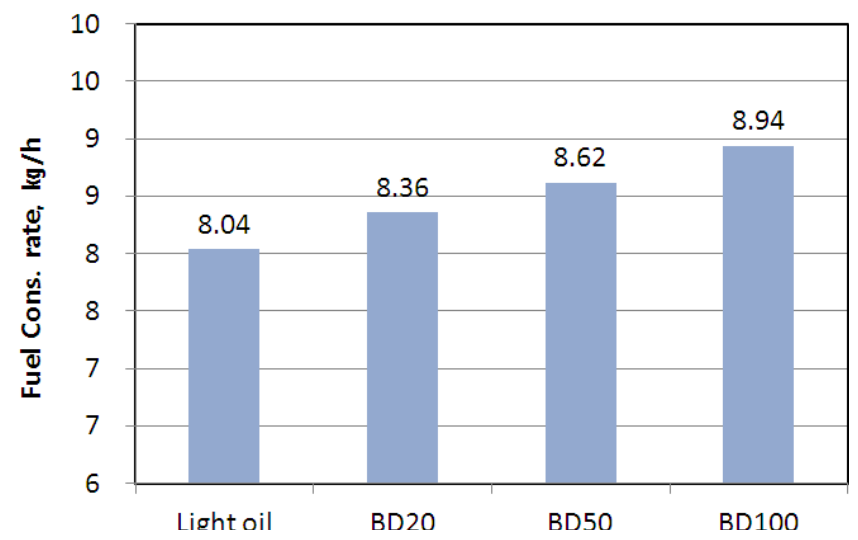

Figure 5. Fuel consumption rates of the diesel engine by four different fuels. 
$\mathrm{CO}_{2}$
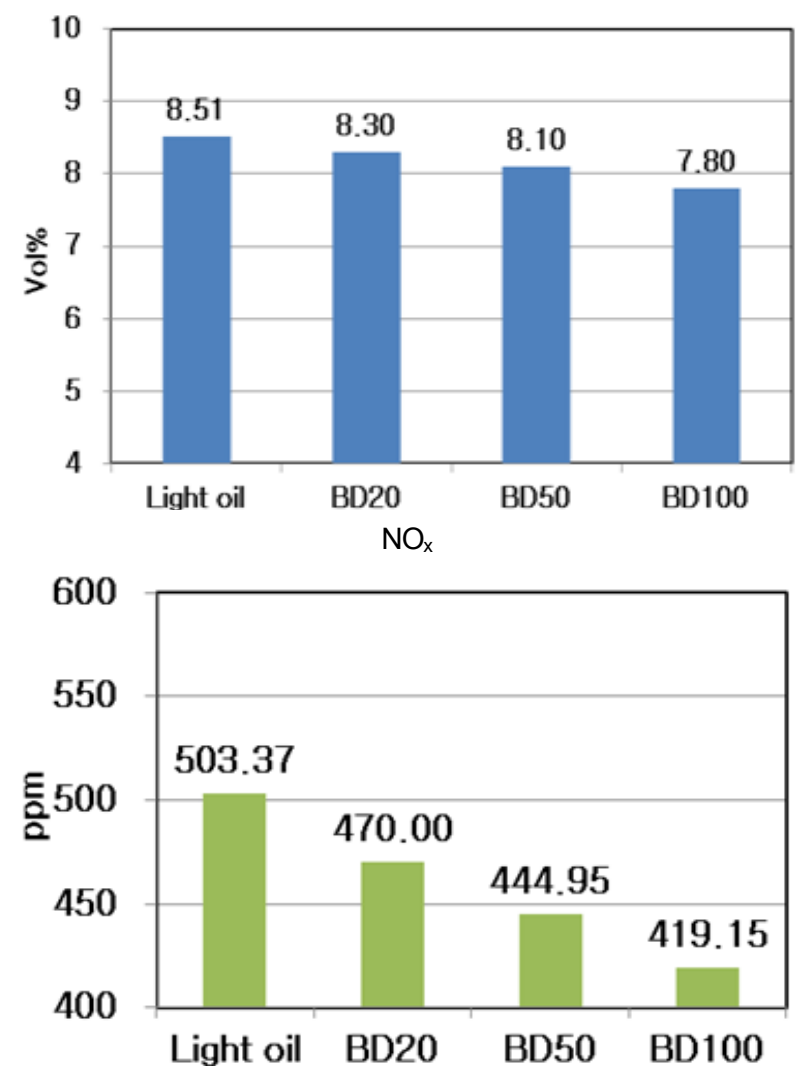

$\mathrm{CO}$
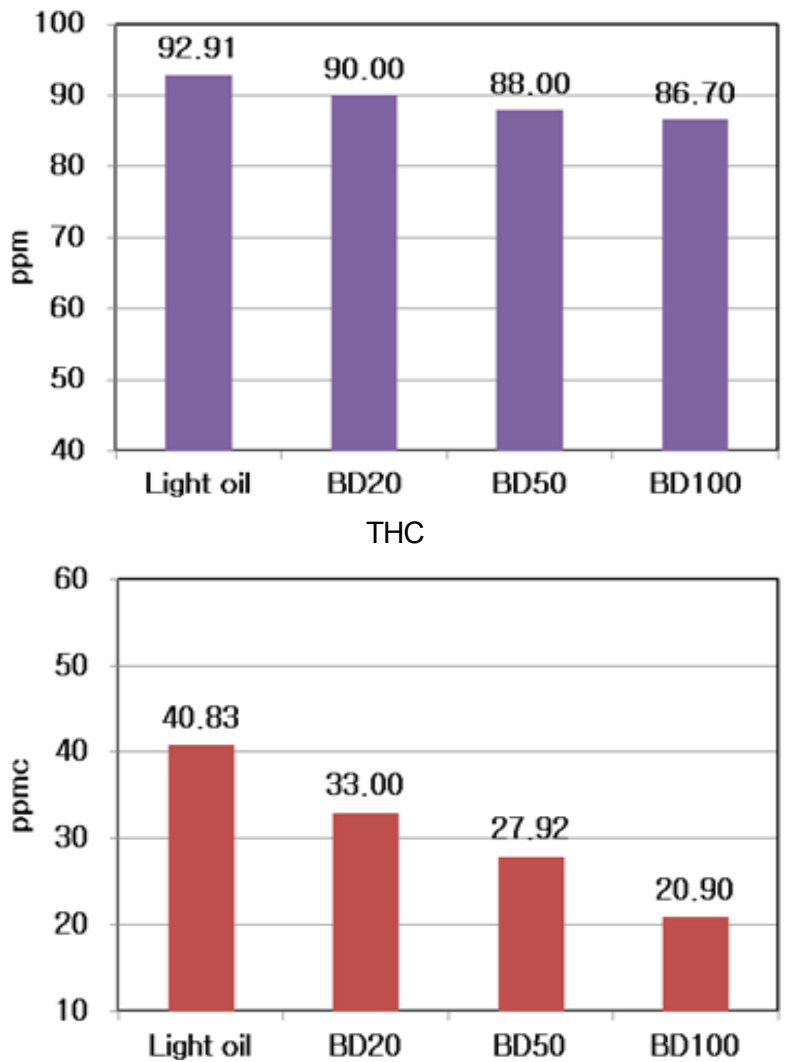

Figure 6. Exhaust gases produced by four different fuels at engine running condition of 2,600 rpm with $120 \mathrm{Nm}$.

Table 4. Particulate matters of the engine of four fuels

\begin{tabular}{ccccc} 
& PTmass $(\mathrm{g} / \mathrm{h})$ & WFi $(\mathrm{kW})$ & $\mathrm{PM}(\mathrm{g} / \mathrm{kWh})$ & Remark \\
\hline Light oil & 14.84 & 428.8 & 0.0346 & US EPA Diesel engine exhaust gas regulation : \\
BD20 & 13.09 & 426.6 & 0.0307 & $19 \leq \mathrm{kW}<37$ \\
BD50 & 12.13 & 420.3 & 0.0288 & PM level for Tier $4<0.3 \mathrm{~g} / \mathrm{kWh}, 0.03 \mathrm{~g} / \mathrm{kWh}(\mathrm{Kang}, 2009)$ \\
\hline BD100 & 10.23 & 417.4 & 0.0245 & \\
\hline
\end{tabular}

ppm and 86.70 ppm in light oil, BD20, BD50 and BD100, respectively, revealing that as $\mathrm{BD}$ content increased $\mathrm{CO}$ emission amount decreased. THC (Total Hydro Carbon) amount in the exhaust gases decreased as biodiesel content increased as showing 40.83 ppmc in light oil and 20.90 ppmc in BD100. In general, less noxious gases were produced as more BD content in the fuel.

\section{PM amount}

Particulate matter is an important index to judge engine performance. Level of PM amount is decreasing as engine designing technology advances and public awareness of environment increases. PMs were collected at each mode and analyzed later. Table 4 shows PM amount of the four different fuels run diesel engine. PM amount of light oil engine and BD20 engine was $0.0346,0.0307 \mathrm{~g} / \mathrm{kWh}$, respectively, that is far less than Tier 4 class tractor PM emission standard, 0.3 $\mathrm{g} / \mathrm{kWh}$, in the year of 2008, but it can't satisfy the PM emission standard of 2013, $0.03 \mathrm{~g} / \mathrm{kWh}$ (Kang, 2009). Considerable emission quantity, about $90 \%$, was cut in the Tier 4 emission standard of 2013 than 2008 tier standard. According to Personal information (2006), PM amount of BD20 engine and light oil engine was $0.206 \mathrm{~g} / \mathrm{kWh}$ and $0.21 \mathrm{~g} / \mathrm{kWh}$, respectively, of which the tested engine was 3 cylinder diesel engine. In this investigation, only BD50 and BD100 diesel engine could pass the PM standard of 2013. 

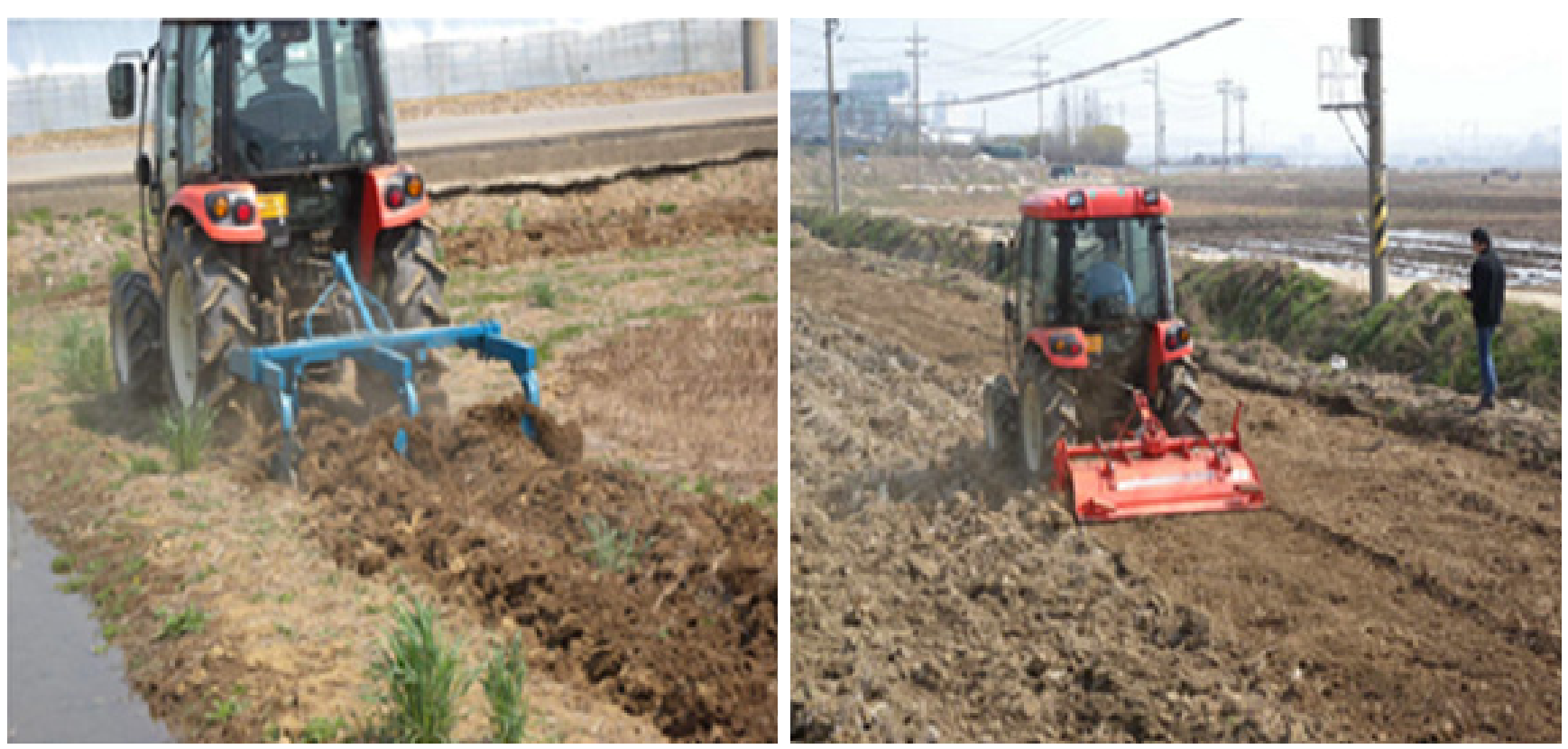

Figure 7. Plowing and rotary tilling in the paddy plot.

\section{Work performance in the field}

The tractor mounted with the diesel engine was put on the field works of plowing and rotary operation, the major tractor operations in the faddy plot. Two fuels, BD20 and light oil, were tested for fuel feasibility in the tractor engine. The tractor operater was the same person on the two operations and the two works were carried out by the same condition and the same patten in the one plot, so we assumed that errors of operater and surrounding were ignoable. Figure 7 shows the two operations conducted in the

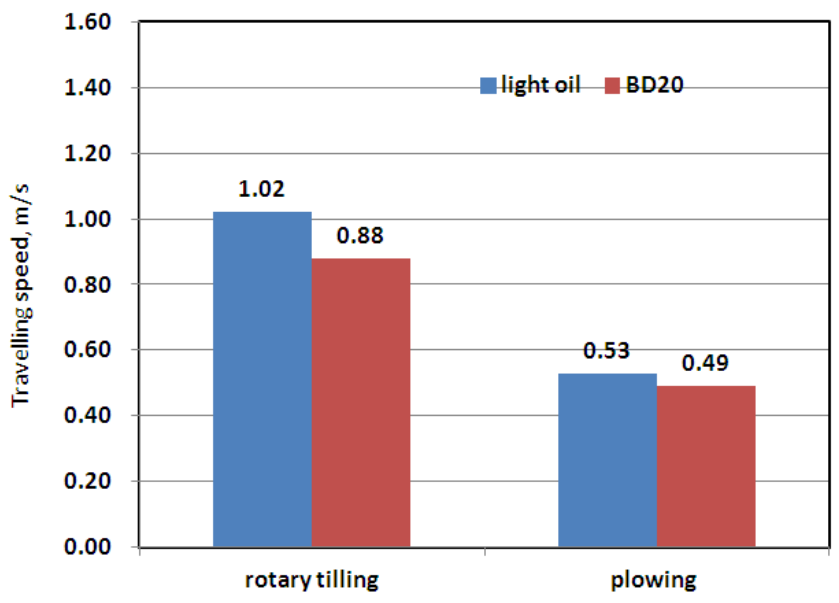

Figure 8. Performance comparison of the tractor works fueled by two fuels, BD20 and oil. paddy plot for this study.

Figure 8 shows the work performance of the tractor mounted with the diesel engine by two fuels, BD20 and light oil. Obviously in both case, light oil tractor was better than BD20 tractor by $13.7 \%$ in rotary tilling and $7.5 \%$ in plowing. However, BD20 tractor had no troubles in both operations in terms of power and no unexpected engine stopping.

\section{Conclusions}

With four different fuel types of animal-fats biodiesel, performances of a four cylinder diesel engine for tractor were evaluated in terms of power, exhaust gases and temperatures, particulate matters (PM) and field works capacities. No significant differences observed in the engine performances including power output and exhaust gases emission rate. No significant power difference observed between the various fuels including light oil on the engine running, however, amounts of noxious exhaust gases including $\mathrm{CO}_{2}$ and $\mathrm{NO}_{\mathrm{x}}$ decreased as biodiesel content increased in the fuels. Field performances of animal-fats biodiesel tractor were investigated by conducting plowing and rotary operation in the plot. Tilling and rotary performance of light oil tractor and BD20 tractor in the field were compared, in which about $10 \%$ travelling speed difference on both operations were 
monitored that showed light oil tractor was superior to BD20 tractor by $10 \%$. Animal-fats can be an alternative fuel source replacing light oil for agricultural machinery and an environmental friendly fuel to nature.

\section{Conflict of Interest}

No potential conflict of interest relevant to this article was reported.

\section{Acknowledgment}

This study was carried out with the support of "Research Program for Agricultural Science \& Technology Development (Project No.PJ006461)", National Academy of Agricultural Science, Rural Development Administration, Republic of Korea.

\section{References}

Choi, S. H., Y. T. Oh and C. H. Lee. 2006. The characteristics of biodiesel fuel as an alternative fuel of an agricultural engine. Journal of Biosystems Engineering 31:115-120.

Choi, S. H., Y. T. Oh and G. H. Kim. 2007. Characteristics of durability and emission with biodiesel fuel (5\%) in a common rail direct injection engine at seoul-10 mode. Journal of Biosystems Engineering 32:97-101 (In Korean, with English abstract).

Goodfellow, J. 2010. Biofuel production from animal fats:
A north American perspective. http://worldrenderers. org/11.pdf.

Hofman, V. 2003. Biodiesel fuel: NDSU Extension Service. February. North Dakota State University, Fargo, USA.

Kang, S. K. 2009. Exhaust gas reduction strategy of construction and agricultural machinery for green growth. Machinery Industry 2:120-132.

Kim, Y. J., Y. K. Kang, K. C. Kang and Y. S. Ryou. 2008. Fuel qualities of different biodiesels in the gun type burner. Journal of Biosystems Engineering 33:124-129 (In Korean, with English abstract).

Kim, Y. J., S. H. Park, C. K. Kim, D. H. Im, H. J. Kim and S. C. Jung. 2010. Investigation of adaptabilities of biodiesel for agricultural tractor. Journal of Biosystems Engineering 35:10-14.

Kim, Y. J., S. H. Park, C. K. Kim, D. H. Im, Y. Jang and S. S. Kim. 2011. Endurance test of biodiesel fueled tractor engine. Journal of agricultural science and technology B1(1):1025-1031.

Kim, Y. J., S. H. Park, Y. J. Kim and C. K. Kim. 2012. Fuel qualities and combustion characteristics of animal fats biodiesel for agricultural hot air heaters. Journal of Biosystems Engineering 37:296-301.

ISO. 2007. Steady-state test cycles for different engine applications. in: part 4. ISO 8178-4. International Standard.

Personal information. 2009. Unpublished Engine Test Report.

Prankl, H, H. Schaufler, H. Lampel, J. Zierfub, A. Burgsteiner and P. Prinz-Hufnagel. 2006. Engine Tests. FJ-BLT Wieselburg. Austria.

Wilson, A. 2003. Biodiesel: a cleaner, greener fuel for the 21st century. Environmental Building News 12:1-9. 